Canadian University Music Review

Revue de musique des universités canadiennes

\title{
Musica in Absentia: Bishop's Faculty of Music, 1866-1947
}

\section{Tom Gordon}

Volume 11, numéro 2, 1991

URI : https://id.erudit.org/iderudit/1014106ar

DOI : https://doi.org/10.7202/1014106ar

Aller au sommaire du numéro

Éditeur(s)

Canadian University Music Society / Société de musique des universités

canadiennes

ISSN

0710-0353 (imprimé)

2291-2436 (numérique)

Découvrir la revue

Citer cet article

Gordon, T. (1991). Musica in Absentia: Bishop's Faculty of Music, 1866-1947.

Canadian University Music Review / Revue de musique des universités

canadiennes, 11(2), 33-50. https://doi.org/10.7202/1014106ar

(c) Canadian University Music Society / Société de musique des universités canadiennes, 1991
Ce document est protégé par la loi sur le droit d'auteur. L'utilisation des services d'Érudit (y compris la reproduction) est assujettie à sa politique d'utilisation que vous pouvez consulter en ligne.

https://apropos.erudit.org/fr/usagers/politique-dutilisation/ 


\section{MUSIC IN ABSENTIA: BISHOP'S FACULTY OF MUSIC, 1886-1947*}

\section{Tom Gordon}

The powers of persuasion of the Reverend Dr. Thomas Adams, Rector of Bishop's College and principal of its University from 1885-1899 are detailed in the centenary history of Bishop's University. Adams could conscript anyone to virtually any task. Witness is provided in anecdote:

An observer quoted a typical conversation:

Adams: "Now you play the organ in chapel next Sunday."

Colleague: "But I've never played the organ."

Adams: "Oh, well, you can." And he did.

(Masters, 1950: 81)

Offered as a testament to Adams' personnel and management skills of the strongarmed variety, the story points no less to an attitude toward music that could safely be regarded as the institution's own during much of its first one hundred years. In a school founded on the twin poles of Anglican Divinity and liberal arts, music was a liturgical necessity, an aesthetic nicety, and a budgetary non-entity. And yet, this same institution, under the same Rev. Dr. Principal Adams, established in June of 1886 the first University Faculty of Music in Québec, the second in the entire Dominion of Canada. Phantom though the Faculty was in the University's history, it led a paper life of over sixty years, bestowed degrees on some twenty musicians, and if only obliquely, contributed to the health and development of colonial musical institutions in the post-confederate era.

To unfold the story of an anomalous Faculty which had neither professor nor resident student across its more than half-century existence, one looks first to the origins of Bishop's University itself. The University's original charter of 1853 empowered it to grant degrees in music. But, like the University of Trinity College in Toronto, founded only a year earlier and with the same degreegranting powers, Bishop's did not offer Proceedings in Music until the 1880's. The decision to establish a Faculty of Music at that time can probably be

* This paper was read in an earlier version at the 1987 CUMS/SMUC conference in Hamilton, Ont. 
attributed to three things:

1 the initiative (and unembarrassed self-interest) of a few individuals;

2 a copy-cat effect that seems to have characterized Bishop's mimicking Trinity in Toronto on more than one occasion, and in this instance could be related to potentially lucrative financial prospects;

3 and, more nobly, a perceived need for universities to intervene in music education in the young Dominion.

To elaborate the noble cause first, there was, by the 1880's, a crisis brewing for music in Canada. With post-Confederation population growth and prosperity, leisure and aesthetic entertainment became a "growth industry." Every town could support a private music teacher; the cities sustained dozens. And while there had been a stream of musicians into the colonies from the beginning of the nineteenth century, supply could not keep up with the demand. Alongside the many legitimate musicians offering instruction, there were many charlatans. The crisis was articulated in the Toronto Musical Journal in June, 1887:

Now, there are but few Canadian towns of any importance which do not overflow with teachers, and surely there must be thousands of intelligent young people, willing and able to take full advantage of musical instruction. Yet, what awful trash do we constantly hear! What wild scamperings across the long-suffering piano! What silly, sentimental stuff is wailed forth by some of our "very musical" young ladies! I cannot blame them, for how can you expect people who have never, perhaps, heard one note of good music in all their lives, to perform and appreciate what they cannot understand! (Cited in Kallmann 1960: 187)

The professional musicians of English Canada, largely British immigrant organists who had settled in the cities of Montreal, Toronto, Hamilton, and Ottawa in increasing numbers, began agitating for some means of establishing standards and licensing for musicians ${ }^{1}$. One response can be recognized in the emergence in major centres of a number of conservatories of music, offering instruction, examining, and bestowing diplomas to its associates and licentiates. And while the conservatories addressed standards of music teaching, the next echelon, teaching the teachers, would be served by the universities. In 1883 the University of Trinity College, Toronto published its first music syllabus and began administering examinations leading to a Bachelor of Music degree. In

${ }^{1}$ In this respect they mirrored the ranks of the acknowledged and aspiring professions of late nineteenth-century Canada where professional self-government was being instituted both for the assurance of acceptable standards of service and for the economic protection of the professional himself. See Bliss 1972: 180-185. 
1886 four degrees were conferred; by 1891 , degrees had been granted to 89 from among the 193 students who had matriculated ${ }^{2}$.

The Trinity Toronto arrangements offered a tempting model for Bishop's. On June 23, 1886 Chancellor Heneker read a letter to the business meeting of Convocation from Rev. F.J. Lloyd advocating the establishment of a Faculty of Music. A resolution was drafted and met with unanimous consent:

That a Faculty of Music be and is hereby established in this University and that the Proceedings in Music of the University of Trinity College Toronto be adopted as a Statute of this University. (Convocation I: 383)

At the same meeting a committee was struck to implement the faculty, comprised of the Venerable Archdeacon Roe (who would become the Registrar of the Faculty of Music), Mr. A.D. Nicholls, the aforementioned Rev. F.J. Lloyd, Professor Couture (organist at the Cathedral of Montreal) and Mr. William Reed (organist at St.Peter's Church, Sherbrooke). The Committee was also empowered to

correspond with eminent Doctors of Music in England, and to appoint from among them a Board of Examiners in Music for this University. (Convocation I: 385-386)

The Committee did its work with dispatch: Trinity's Proceedings in Music were published in the Bishop's 1886-1887 calendar; an eminent Doctor of Music, George Mursell Garrett, was appointed Examiner; and in the spring of 1887 two matriculants sat the Examination for Bachelor of Music, Part I. They were the self-same Rev. F.J. Lloyd, and the self-same Mr. William Reed, organist at St. Peter's Church, Sherbrooke and occasional teacher of singing at Bishop's College School.

It is difficult to escape a suspicion of self-service in the inception of the Faculty, a suspicion that remains hard to dispel as one peruses the slender and sporadic list of its students. Its first generation of graduates provided its second generation of examiners, who in turn led their own portegés through the examination cycle to degrees and ultimately to positions of being examiners. Of the thirty-four men and women who passed through the Faculty between 1886 and 1947 almost all can be slotted somewhere into this cycle of mentors and protegés. The University's role remained, on the whole, as distant and detached as suggested by its initial

2 A small furore emerged over Trinity's degree-by-examination factory. See Gaynor Jones,

“'Exam Wars' and the Toronto Territorial Connections”, in this issue. Kallmara, 1960; 191-192 gives 1891 as the date when Trinity ceased to administer exams outside Canada. 
decision to adopt another university's syllabus in music. Bishop's seems to have lacked the wherewithal, the expertise, and the institutional will to administer its own Faculty of Music. Two well-intentioned and quite diverse attempts to invigorate music and its Faculty at Bishop's occurred within the last decade of the nineteenth century. Neither succeeded. And during the ensuing fifty years the University in reality did little more than lend its seal to the occasional scholarship of others. Its Faculty of Music remained in absentia.

What follows then is a chronological re-telling of that interesting first decade of Bishop's Faculty of Music, spiced with a few demi-vignettes of its proponents. The conclusions to be drawn reside mostly in that historical nether-world of what-ifs. Tangibly, they serve to document the attempts to legitimitize the serious study of music in Canada even if the realization would have to occur elsewhere.

Circumstances considered, the Faculty of Music got off to a noble start in 1887. The Proceedings in Music it adopted from Trinity promised an vigorous standard, and its eminent English examiner assured that this standard would be upheld. The syllabus required a candidate for the degree to be a clergyman, a graduate of a recognized university, a barrister-at-law, or someone who could produce a certificate stating that he had been employed for five years in the study and practice of music (Convocation I: 383-385). Once admitted, candidates would have to pass (at a mark of 60 or higher, considerably more stringent than the requirement for Bishop's students "in course") a cycle of three examinations, taken at least a year apart. Before proceeding to the final of the three examinations, candidates had to present the University examiner with an original composition, duly notarized as being the candidate's own work, and rather uninspiringly called "the exercise." The exercise was to be a work of 18 to 20 minutes performance length for SATB chorus with accompaniment by string orchestra (with or without organ). The examinations focussed on theoretical and compositional technique, with a smattering of music history and analysis. By the level of the final Bachelor of Music Exam, the requirements included harmonic writing in five-parts and a chromatic style, species counterpoint, and canon and fugue in four voices. It suggests a level of mastery that not all Bachelor of Music students today would be able to equal.

The University's first examiner, Dr. George Garrett, could certainly be judged as suitably "eminent." Born in 1834, he had been a pupil of Samuel Wesley and assistant organist at Winchester Cathedral, prior to assuming the post of organist at St. John's College, Cambridge in 1857. In 1874 he became organist to Cambridge University as well as its examiner in music. Like many another English organist, he was a composer of cantatas and organ music. His acceptance 
of Bishop's none too onerous request to serve as examiner, may have been occasioned by a personal connexion with Bishop's Rev. Principal, Thos. Adams. Both had been at St. John's, Cambridge at the same time. Needless to say, Garrett never set foot in Canada.

Neither of Bishop's first two candidates for the Mus. Bac. actually completed the degree. After passing the first exam, in June 1887, the Rev. F.J. Lloyd vanished from music without a trace, though the name Lloyd would continue to figure at Bishop's for some time. William Reed presents another story and offers the first of a few near-misses with destiny suffered by Bishop's musicians.

William Reed was one of several organists who went on from a posting at St. Peter's/Sherbrooke to positions at major churches in Protestant Canada. Extraordinarily, he was Canadian-born, an oddity among musicians, especially organists until well into the twentieth century. Before coming to Sherbrooke in 1884 he had studied at Keble College, Oxford, where he had won the position of College organist. He remained in Sherbrooke for four years before he moved to appointments at St. Andrew's Presbyterian (Toronto); American Presbyterian (Montreal); and Chalmers United (Québec). A composer of sacred and organ music, some of his works had been issued by publishers in England ${ }^{3}$, but his career was cut short thirty years before his death by deafness, and occupational disability that only a Beethoven could surmount.

The University offered examinations annually through 1891 , but without leading a candidate to the baccalaureate degree. One candidate who, like Reed and Lloyd, never completed the degree but went on to earn recognition in Canadian musical history, if only of the footnote variety, was R. Stanley Weir. Weir took the first exam for the Mus. Bac. in 1981, and seems not to have gone beyond that level. His career would be outside music in any event, first as a lawyer, then as a judge of the Exchequer Court. A published poet, Weir's musical activity was confined to holding positions as organist at a number of smaller Montreal churches throughout his life. His claim to fame lay in the fact that in 1906 he wrote the English words that would become the official text of Calixa Lavallée's $O$ Canada until the purge of all those "stand on guard for thees" of 1980.

Not until 1894, six years after the decision to establish the Faculty of Music, was there any activity beyond the annual examination. In February of that year the College Council received a request from Mr. Percival J. Illsley, organist to St.

${ }^{3}$ Particularly to be noted are two "Grand Choeur", for organ published by Charles Vincent in London, a "Triumphal March" published by Oliver Ditson, New York (1908) and a "Sortie triomphale" published by H. W. Gray, New York (1922); all for organ. 
George's Church, Dominion Square, Montreal. Illsley wondered if there was anything in University statutes to prevent a woman from sitting the examinations for the Mus. Bac. The Council saw no objection and with the ratification of the amendment by the meeting of Convocation, Music became the second of the University's faculties to be open to women. (Medicine had begun admitting women three years earlier.)

Illsley's request was not an idle inquiry, and it appears that the College Council recognized in the man the agent of getting its moribund music faculty into operation. Born in 1865 in Staffordshire, England, Percival Illsley had been articled to J.B. Lott, organist to Lichfield Cathedral, and had held a variety of minor posts in England, including that of organist to the Marchioness of Hastings, prior to his emigration in 1891. At the time of his emigration he was an Associate of the Royal College of Organists, later becoming a Fellow. He would acquire his first Mus. Bac. from Trinity, Toronto. A man whose bearing and manner spoke forcefully of the conservative traditions of English cathedral music, his thirty-year tenure at St. George's in Montreal was noted for two things:

[The St. George's choir] was one of the few church choirs of the time composed of men and boys only; and it was noted for its reverence and devotion to liturgical Anglican church music. (Collard, 1960: 6)

Reverence and devotion also extended to Illsley's own sense of mission - that of entrenching his tradition in Canada. And he went about it with determination. At the same time he was not, by the testimony of his contemporaries, a remarkable musician ${ }^{4}$.

The College Council recommended Illsley to Convocation in the spring of 1894 for the degree of Mus. Bac. ad eundem and at the June public meeting he became Bishop's first, if honourary, music graduate. It was clearly an honour bestowed with expectations - expectations fulfilled the following October when a letter from Illsley was read at the monthly meeting of the College Council.

The Council was informed that certain organists having formed an Institution called "The Dominion College of Music" whose headquarters were at

${ }^{4}$ An open letter signed by Oliver Knapton in 1933 suggests the circumstances that led to Illsley's being named to the Lambeth Doctorate: "This degree was presented to him on account of 'his services to Church Music in the colonies', but I should imagine the real reason was that in his early days he was private organist to Her Grace the Marchioness of Hastings and the connexion was kept up all his life; however he was a very able musician but I doubt whether he would have obtained the degree but for the friendship of the Marchioness" (Knapton 1933: 133). 
Montreal sought for some form of affiliation ... It was decided to refer the matter to the Dean of Faculty of Music and to Dr. Garrett, and the Principal was authorized to write to Mr. Illsley and inform him what steps had been taken. (Council III: 444)

For the next fifteen months frequent correspondence passed between the University and the Dominion College organists, with Illsley as their spokesman. The terms of affiliation were finalized at a meeting of Convocation on 20 October, 1895 and ratified at the meeting of 11 January, 1896 once the University received notification from the province that the Dominion College had received its papers of incorporation.

The affiliation was comparable to the link that Trinity College Toronto had formed with the Toronto Conservatory. It provided that associates and licentiates of the Dominion College of Music would be exempt from the first and second (respectively) examinations leading to the Bachelor of Music Degree at Bishop's In return for these exemptions (and for a modest financial allowance in the University's favour) the Dominion College would channel its most advanced students to the University for their terminal examination and degree. In effect, the Dominion College of Music became Bishop's Faculty of Music, preparing students for matriculation, administering examinations, conferring the preparatory diplomas, and most importantly, providing the instruction that would enable candidates to pass the Baccalaureate exam ${ }^{5}$.

Even as the negotiations for affiliation were going on, Bishop's Faculty of Music was flooded (relatively speaking) with new candidates. After receiving no new registrants in four years, and still having conferred no earned degrees, the Faculty of Music administered four examinations in the fall of 1894, one of which was written by Illsley's female protegé Miss Jennie Howard, and another by the bursar of the Dominion College of Music, Horace W. Reyner. The affiliation was rich in promise. The Dominion College's rostrum included the most prominent church musicians in the milieu of English Montreal. Within two years of incorporation it had its offices and teaching facility on Dorchester Street. And it could announce proudly, five years after its founding, that having administered examinations to only four candidates in its first year, it now had more than one hundred candidates annually (Musical Redbook 1907: 135).

While the Dominion College quickly began to fulfill the expectations of the University, the reverse does not appear to have been true. It is clear that Illsley

5 Illsley himself contributed an article to the University's student magazine, The Mitre, in which he describes the Dominion College of Music as "forming the music faculty of Bishop's College" (Mitre VII: 35). 
hoped that the affiliation would permit him or some other representative of his organization to have a voice in the affairs of the University, presumably to assure the health and advancement of the Faculty which he was essentially now administering for the University. In the affiliation proposal Illsley had requested to

have a representative (to be appointed by yourselves) upon your Executive Board or Corporation; one who has taken the degree of Mus. Bac. preferred (Corporation III: 205)

But the University had declined this request, recommending instead that the University appoint its own representative to the Council of the Dominion College. It also offered Illsley the right, as a graduate and member of Convocation, to address his concerns in that forum, open - at least theoretically - to all on whom Bishop's had conferred degrees. Further, the University agreed to lend the name of its Chancellor, R.W. Heneker as an honourary patron of the Dominion College. The University's reluctance to give more than nominal support was evidenced in other ways.,

At the May 2, 1901 Business Meeting of Convocation a letter from the Bishop of Montreal was read requesting that the degree of Doctor of Music be conferred on Illsley in recognition of his service in improving church music. The request was denied, and denied again when it was repeated in 1904. Not until 1913, and only after the honourary "Lambeth doctorate" had already been bestowed on Illsley ${ }^{6}$, did Bishop's accede to a third request to offer a doctoral degree to Illsley. And although the official programme of convocation identifies Illsley's doctorate as "honoris causa", the Illsley papers at the National Library in Ottawa contain the manuscript of a composition of the description, and in the same notarized format as required in the Bishop's syllabus for the acquisition of the degree Doctor of Music in course.

Illsley's impatience with the University is suggested in correspondence read at the October 17, 1902 meeting of the College Council. The minutes record:

A letter was read from Mr. P.J. Illsley of Montreal in regard to the examinations and degrees in Music of the University. It was recommended that the Principal confer with the Registrar with a view to more widely advertising the musical work of the University. (Council IV: 287-288)

6 The Lambeth Doctorate (Mus.Doc. Cantuar) was not a degree honoris causa granted by the University, but a title bestowed by the Archbishop of Canterbury. In reference to Illsley's widely broadcast Lambeth Doctorate, Oliver Knapton wrote that the degree seems

to be of little or no use except to make the bosom of the recipient swell with pride. I cannot see how they advance the cause of music in the Church in any degree (Knapton 1933: 133). 
The University's response to Illsley's request to more widely advertise its musical degrees was to appoint him sub-registrar of the Faculty of Music, an unpaid position which implied responsibility without authority. Reasonably enough, Illsley did not find the University's response entirely appropriate. While he had already proven himself a clever and energetic administrator through the establishment of the Dominion College of Music, he was ready to let others assume the burdens of management. He was, after all, first a practising musician, then a teacher. When McGill University assumed responsibility for music instruction, first through its conservatorium, founded in 1904, and then through its Faculty of Music, established four years later, Illsley offered his services there. He maintained his association with Bishop's until his death in 1924. In the last two years of his life he was formally appointed an Examiner in Music for Bishop's, and there was another slight rush of his protegés to receive degrees. In the end, one is left to conclude that the University either did not have enough confidence in Illsley to promote a Faculty of Music under his administration; or that commitment to the discipline of music was insufficient to sustain the Faculty after an initial flush of interest.

Support for both these conclusions is lent by the other attempt to vitalize music at Bishop's in the last decade of the nineteenth century. That other attempt was closer to home, and for that reason wears a bit more flesh in the University's minute books and student magazine of the 1890's. And because it was closer to home, its failure was the more bitter.

From the onset of the decade, Bishop's found itself continually in consideration of curricular change within its Arts and Divinity Faculties. Some of the considerations were forced on the University by acts of the provincial legislature; some were generated from within. As the total number of students in the University doubled across the decade (from 31 to 69), the range of their studies broadened even more considerably. The decade saw the reintroduction of courses in physics and chemistry, and in political economy and English; of expanded offerings in classics; and of optional lectures in areas as diverse as surgery for divinity students, elocution, and conversational French. After the divisive and disruptive Stigma riots of $1890^{7}$, student opinion was cautiously voiced, it seemed to be listened to. Thus on March 25, 1891 the College Council received a petition signed by 27 students requesting

\footnotetext{
7 Nearly one hundred years later, the Stigma Riots of 1890 seem a comically mild affair. At the time, however, they threatened the very life of the institution. More protest than riot, the affair originated with a petition disparaging the food and "domestic management" of the institution. The College Council found the petition to contain "offensive language" and summoned the Bishop of Québec to its aid in disciplining the responsible students. While the severe sentences meeted out were eventually all but rescinded, the authority of the University, and particularly its Principal, were greatly undermined (Masters 1950: 79-80).
} 
that provision should be made for the study of music and that a lecturer of Music should be appointed to give lectures on that subject. (Council III: 302).

The Principal (Rev. Dr. Thomas Adams) read letters from Mr. Hudspeth, the new lecturer in Sciences who was a talented amateur in music, and from Mr. Arthur Dorey, the new organist at St. Peter's in Sherbrooke. Both suggested content and method, should classes in music be formed. The College Council responded in the way that College Councils always do: they struck a Committee to study the issue and report back. The Committee made periodic reports, but there was no immediate action. If the University responded directly at all, its response was framed in the resolution of Corporation passed on May 30 that same year:

That no extra subject, such as music or shorthand be allowed to interfere in the slightest degree with regular work. (Corporation III: 39)

But the seeds of having music on campus had been sown, and all the people who would make the most concerted efforts over the next eight years to have them take were in place.

The principalship of the Rev. Dr. Adams was beset with struggles across its fourteen years. Born in 1847, Adams would combine the careers of both his farther (an Anglican clergyman) and his uncle, Dr. J.C. Adams, the Cambridge mathematician who discovered the planet Neptune. He was portrayed as a fine scholar and a forceful personality. The University prospered under his stewardship, due as well to the fact that he was

also a man of the world, able to enlist the support and interest of prominent men outside the institution. (Mitre X: 141)

And yet he had his weaknesses. More than once he drew censure from his colleagues, and even from the Bishop of Québec for inappropriate demeanor and neglect of discipline (euphemisms for unspecifiable nineteenth-century indiscretions). But one of his more laudable weaknesses was clearly music. Together with Chancellor Heneker he presses for the Dominion College affiliation. More on a personal level, he continually dug into his own slender pocket to bring an organist to play on campus, or to purchase music for the chapel. His occasional requests for reimbursement to the Board of Trustees were usually turned down.

R.W. Hudspeth, one of those who endorsed the student's scheme for instruction in music, had been appointed a lecturer to the University in 1887 at the salary of $\$ 100$ per annum. A scientist, he was also a master in the school, and an 
accomplished amateur painter who would merit an Honorable Mention at the Paris Salon of 1933. But he commands our attention here for the role he was often called to play as director of the chapel choir. It was not a continuing role. He was rather the University's hot-shot choral trouble-shooter. Whenever music in the chapel got intolerable, the reverend professors would wring their collective hands at a Council meeting and wonder if Mr. Hudspeth might not be called upon to set the choir right again. Sometimes they even paid him!

But the most intriguing figure by far in the little drama of music at Bishop's over the next several years was Arthur Dorey. Intriguing and frustrating, since Dorey was the most lively character to have leapt off the page. Yet he vanished in 1899, almost without a trace, leaving questions unresolved. What can be documented is only that he was an English organist (comme il faut) who arrived in Sherbrooke in 1889 to assume the position of organist at St. Peter's. For seven years he was listed as Organist and Music Master in the Calendars of Bishop's College $\mathrm{School}^{8}$. He remained in the area for ten years during which time he implicated himself in every aspect of musical life in the area. From 1899 to his death in 1921 he held a position at Christchurch Cathedral in Ottawa.

If the facts of his life are bare, there is, nonetheless, much colour. From the long list of organists at St. Peter's between 1841 and 1941 Dorey was singled out as a

distinguished musician, remembered not only for his fine playing, but for the dignity of his bearing and deportment at this instrument. (St. Peter's Parish 1947: 46).

During the decade of monster concerts south of the border, Dorey inaugurated a series of mini-monster concerts in the Townships, bringing together all the episcopal choirs from the region for festivals of oratorio and cantata singing. He was a composer who published anthems and music for the liturgical service at his own expense. Frustratingly, almost all of this seems to have vanished. The loss is particularly regrettable for the full choral service composed for the Jubilee festivities of the University in 1895 and dedicated to Thomas Adams. The Mitre's Jubilee report described it as "especially touching and reverent composition" (Mitre II: 107).

When the students at Bishop's got their tongue with the initiation of the The Mitre in June of 1893, the admirable activities of the talented Mr. Dorey were lauded in every issue.

${ }^{8}$ Across the B.C.S. Calendars Dorey's credentials underwent a measure of inflation from A.R.C.O. to F.R.C.O. and finally to "late organist Alexandra Palace, London" (Patriquin 1978: 108). 
June, 1893: Too much praise cannot be given to Mr. Dorey for his strenuous efforts within the past year to raise the level of musical Church Services in this neighborhood. (Mitre I/no.1: 4).

October, 1893: There is a rumor afloat that Mr. Arthur Dorey, our talented organist, purposes [sic] giving a series of organ recitals in the chapel during the coming year. It is sincerely hoped by all lovers of good music that his report is true, since Mr. Dorey's recitals are like gleams of sunshine which help to drive away the blues which are attendant upon such a lack of music as the students suffer from here. (Mitre I/no.2: 8).

October, 1894: The College authorities have made arrangements with Mr. Dorey to introduce the study of vocal music in the University. Opportunities of this kind ought not to be neglected. (Mitre II: 6)

December, 1894: Since the introducing of a piano into the Divinity House a class has been organized for all candidates for Holy Orders ... Mr. Dorey's interest in the men merits our best appreciation of his services. (Mitre II: 30)

From the student's effusions much of the tale is told. In September 1894 a special Curricular Sub-committee of Convocation recommended the institution of twice-weekly courses in vocal music, particularly for the attention of divinity students. These were accompanied by similar courses in elocution and conversational French. The Board of Trustees approved, and on October 15, 1894 Dorey was hired as the University's singing instructor at the princely sum of $\$ 50$ per annum. But contrary to the University's student's impression, Dorey was never "our" organist. His position at St. Peter's would have prevented him from carrying out the regular duties of University organist. And further, though the University was happy to benefit from Arthur Dorey's talents both as organist and as composer and choral master during its elaborate Jubilee Festivities in June of 1895 , it was reluctant to compensate him for any of these services. More than once Principal Adams' requests for consideration for Mr. Dorey were "held over" or "referred."

Actually the whole question of the University's organist was to come open during the following year, 1896. As the University entered its second half century, a number of important administrative changes were implemented at the joint urgings of the Bishops of Québec and Montréal. One of these was to give the School Headmaster his proper seat in the chapel. This meant taking him off the organ bench which he had occupied for the past seventeen years in the absence of a proper University organist. That propriety having been observed, the University found itself without an organist in the autumn of 1896, and the music in chapel in a deplorable state. 
The committees geared up and by mid-October the Corporation had approved an allocation of $\$ 400$ annual salary for an organist/choirmaster/lecturer in music. The students offered their delighted approval

that there is to be a new organist and choirmaster. Where there are opportunities for having a good choir and choral services, such as we have, there ought to be a resident musical instructor who should, daily give definite and systematic instruction in music. Music should be a subject of study as much as Greek, or Mathematics. Very little can be learned in choirpractice, one hour a week. The choir-boys as well as the men who have not already had some instruction in the Art, should not be left to pick up the tunes for hymns and psalms "by ear," and then depend upon their memory, but to be taught and helped to sing independently. This would not be to their advantage while here only, but would be a great help in after-life, especially in the case of candidates for Holy Orders, who may find it necessary, sometimes, not only to lead the singing in Divine service, but perhaps to sing alone. Furthermore we should not be left to depend upon one another to act as organist. And we might also have a more hearty service at Evensong. We sincerely hope that the report is a true one, and if not, that this suggestion may be instrumental in bringing about such a wished-for condition of affairs. (Mitre IV: 7-8).

What followed brought Bishop to the brink of being one of the first Canadian universities to give serious attention to the study of music.

The Principal duly advertised the position of University organist in the appropriate newspapers (i.e., the London Guardian), and whether by nomination or application the Corporation found itself making a "sweetened" offer on 7 January 1897 to one John E. Barkworth. The University offered \$500, plus room, board, and passage. Barkworth declined but left the door open, and there followed a six-month cat-and-mouse game between University and organist. The University's final offer was $\$ 700$ plus all the extras, a sizable offer for the University to be making (the Principal was paid only $\$ 1250$ at that time).

The University's willingness to carry on negotiations for so long and to so extend its offer was in part occasioned by the fact that it had received few other suitable applications. In part, it must be attributed to Principal Adams' determination to make an appointment that would bring honour to the University, and in part by the calibre of man found in John Barkworth. Born in Beverley, England, in 1858, Barkworth had been to the right schools (Rugby and Oxford), studied with the right composers (Parry, Sanford, and Englebert Humperdinck) and finished with the prestigious Oxford Mus. Bac. He had already chalked up six years of teaching 
as Musical Director of Feltes College, Edinburgh. His suitability to Bishop's rather all-encompassing needs was noted at the meeting of Corporation at which he was recommended for appointment:

Letters and testimonials relating to Mr. Barkworth were read by the Principal who stated that Mr. Barkworth's academic record showed that he was a gentleman capable of Lecturing in the College on Classics, Elementary Mathematics as well as in Philosophy and Literature. (Corporation III: 310 )

The minutes do not indicate whether Mr. Barkworth would also be responsible for carrying coal to start the morning fire. In the end, Mr. Barkworth accepted a more suitable offer from St. George's Cathedral in Ottawa. After he came to Canada, he moved on to Baltimore where in 1901 he became professor of organ at the Peabody Conservatory. During the First War, he returned to England, settling in Cambridge where he wrote operas which held the stage in London in the 1920's. He died in Geneva in 1929.

In the next year of vain searching for a University organist, the discussions were always centred on

a man of the type of Mr. Barkworth i.e., a good musician who was a Graduate and who had specialised in some [subject] such as Philosophy, Literature or Science sufficiently to make him suitable as a College Lecturer. (Corporation III: 327)

Applicants were "remarkably good on the musical side," but never strong enough in the other desired fields. It is unlikely that even had Bishop's been able to entice a man of Barkworth's calibre, that he could have been induced to stay.

Musically, the University was doomed to a long future of tolerating incompetent student organists, hoping someone else would promote its degree-by-examination Faculty of Music, and agonizing over whether it could afford $\$ 15$ to repair waterdamaged organ pipes. For the next seventy years Bishop's was forced to resist the recurrent student entreaties to "give music its place ... and a very prominent one in the College education" (Mitre VII: 260). It encouraged its fair share of musical societies, glee clubs and theatricals, but the "elevating and refining influences" which would be brought in through the scientific study of music were denied its students. With the passing of the Reverend Professor Principal Thomas Adams in $1898^{9}$, so passed also efforts to entrench the study of music in the life of the University. The individual determination of a Percival Illsley or a Thomas

9 Adams suffered a paralytic seizure in August 1898. "From this he never recovered, and it may truly be said that he had worn himself out in the interest of the institution under his charge" (Sherbrooke Record, 1899/12/26). He died on Christmas Day, 1899 in Hertfordshire, England. 
Adams to transplant British cathedral music traditions had fallen on cultural soil not yet ready for cultivation. While the young cities of the Dominion would succeed in establishing the institutions which would guarantee the development of a musical culture, Bishop's microcosm of the great British institutions was too small and impoverished to sustain them. The hard truth is that Bishop's was a struggling little provincial outpost, making a well-intentioned, but essentially futile effort to mirror the pomp as well as the circumstance of its Cambridge model. Bishop's, which was described fairly on the occasion of its fiftieth jubilee as having waged a "brave struggle for existence" (Mitre III: 1), lost the struggle for music.

\section{BISHOP'S FACULTY OF MUSIC, 1886-1947}

\begin{tabular}{|c|c|}
\hline \multicolumn{2}{|c|}{$\begin{array}{l}\text { Dramatis personae } \\
\text { A. University examiners in Music }\end{array}$} \\
\hline $1887-1897$ & $\begin{array}{l}\text { George Mursell Garrett (1834-1897) MusBac; M.A.; } \\
\text { MusDoc University organist and lecturer in music, Cam- } \\
\text { bridge }\end{array}$ \\
\hline $1897-1922$ & $\begin{array}{l}\text { Arthur Henry Mann (1850-1929) MusBac (Oxon) } \\
\text { Organist, King's College Cambridge; Handel scholar }\end{array}$ \\
\hline 1922-1935 & $\begin{array}{l}\text { Albert Ham (1858-1940) F.R.C.O., MusDoc; DCL } \\
\text { (Bishop's 1933) Organist, St. James Cathedral, Toronto; } \\
\text { Lecturer, University of Toronto }\end{array}$ \\
\hline $1922-1924$ & $\begin{array}{l}\text { Percival J. Illsley (1865-1924) MusBac (Bishop's 1894); } \\
\text { MusDoc (Bishop's 1913) Organist, St. George's, Montréal }\end{array}$ \\
\hline $1923-1933$ & Geoffrey E. Holt (-) M.A.; MusBac (Trinity, Toronto) \\
\hline $1925-1936$ & $\begin{array}{l}\text { James W. Bearder (1869-1958) MusBac (Bishop's 1925); } \\
\text { MusDoc (Bishop's 1929) Organist, All Saints Church, } \\
\text { Ottawa }\end{array}$ \\
\hline $1936-193$ & Herbert Sanders (d. 1938) \\
\hline $1936-1947$ & $\begin{array}{l}\text { Graham Godfrey (1890-1955) MusDoc Conductor, } \\
\text { Hamilton Orchestra }\end{array}$ \\
\hline $1936-1947$ & Healy Willan (1880-1965) F.R.C.O.; MusDoc \\
\hline
\end{tabular}

B. Candidates for degrees in Bishop's Faculty of Music

Name

William Reed

Rev. F.J. Lloyd

J. Herbert Logan 1st Exam 2nd Exam MusBac MusDoc 1887

1890 
Name

R. Stanley Weir

P.J. Illsley

J. Edgar Birch

H.W. Reyner

Miss Jennie Howard

W.H. Jackson

J. Angus Winter

J. Marceau

John B. Norton

C.E.B. Price

Philip E. Netten

Miss Edith Walkey

Miss Florence Caldwell

Miss Beatrice Donelly

A.H. Egg

E.M. Brewer

C.G.B. Williamson

G.H.E. Clark

John B. Gatenby

Chas. M. Weddel

Miss Marion E. Lambly

Mrs. Ellen Adair-Seward

Walter Uffelman

Newstead A. Allen

J.W. Bearder

Rev. Moody B. Johnson

Mrs. Ada B. Sparks

John Robb

Miss Edith Merrill

Miss T.M. Woodburn 1st Exam

1891

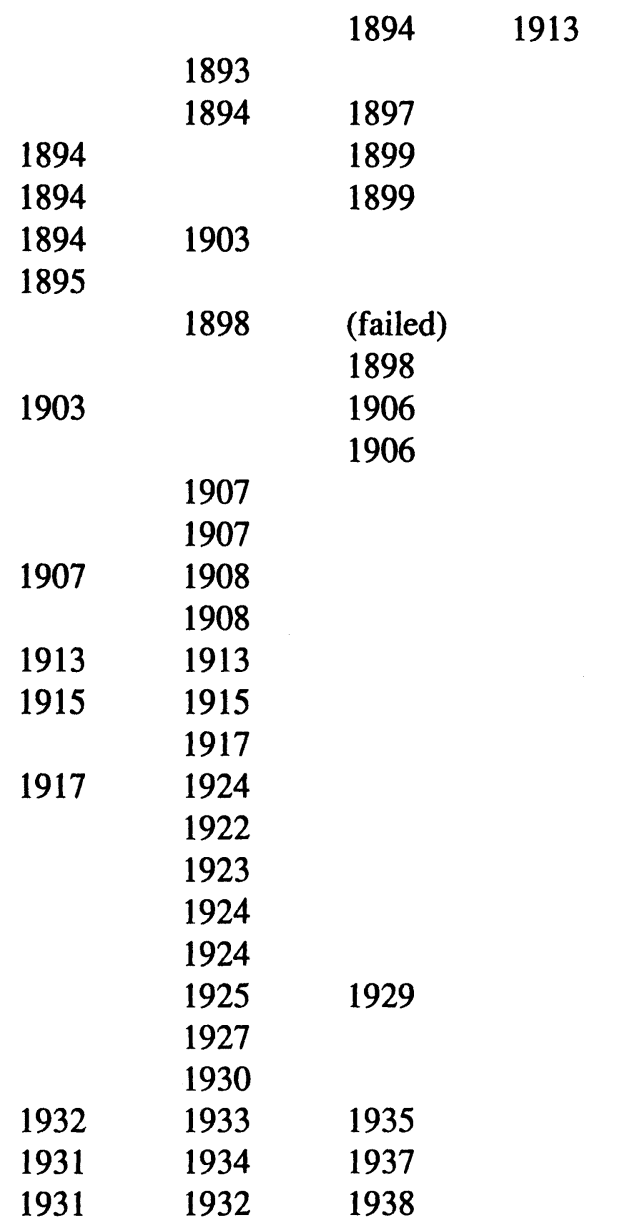

\section{REFERENCES}

BLISS, $M$

1972: "The Protective Impulse: An approach to the Social History of Oliver Mowat's Ontario," Oliver Mowat's Ontario, Edited by Donald Swainson, Toronto: Macmillan of Canada, 1972. 


\section{CALENDAR}

Bishop's University, "Proceedings in Music," The Calendar of Bishop's University, 1885-1936.

COLLARD, E.A.

1960: “All our Yesterdays: Some Memories of St. George's Choir," The Montreal Gazette, (11 June, 1960), p. 6.

CONVOCATION

Bishop's University, "Minutes of the Business Meeting of Convocation, 1854-1950," Three volumes, Lennoxville, Québec.

CORPORATION

Bishop's University, "Minutes of the Corporation of Bishop's University, 1845-1919," Four volumes, Lennoxville, Québec.

COUNCIL

Bishop's University, "Minutes of the College Council of Bishop's University, 1854-1921," Six volumes, Lennoxville, Québec.

\section{KALLMANN, $\mathrm{H}$}

1960: A History of Music in Canada, 1534-1914. Toronto: The University of Toronto Press.

\section{KALLMAN, $\mathrm{H}$.}

1981: Kallman, H., Gilles Potvin, and Kenneth Winters. Encyclopedia of Music in Canada. Toronto: University of Toronto Press.

KNAPTON, $\mathrm{O}$.

1933: “The Mus. D. Degree," The Choir, (Spring, 1933), p. 133.

MACMILLAN, E.

1955: Music in Canada. Toronto: The University of Toronto Press

MASTERS, D.

1950: Bishop's University, The First Hundred Years.

MITRE

The Mitre, 65 volumes, (1893-1958).

MUSICAL REDBOOK

1907: Sandwell, Bernard K. (ed.) The Musical Redbook of Montreal. Montreal: F.A. Veitch.

PATRIQUIN, G.

1978: B. C. S. From Little Forks to Moulton Hill. 2 Volumes, Lennoxville, Bishop's College School. 


\section{ST. PETER'S PARISH}

1947: A History of St. Peter's Parish, Sherbrooke, Diocese of Quebec in Commemoration of the 125th Anniversary of the Founding of the Parish. Sherbrooke, Quebec:

\section{SHERBROOKE RECORD}

1902/12: "Rev. Dr. Adams Dead" The Sherbrooke Record, (December 26, 1902),

WALTER, A.

1969: Aspects of Music in Canada. Toronto: University of Toronto Press. 